\title{
What If You Were A Young Professional? A Scenario on The Critical Grounds of Illhan Tekeli's Course
}

\author{
Gülşah Aykaç1 \\ ORCID: 0000-0002-6003-2704
}

\begin{abstract}
This paper attempts to open a critical discussion of Tekeli's graduate course discussing active citizenship and participation in extension with the labor and work of young professionals (as architects/urban planners/urban designers) in our era of urban crisis. With this aim, the fragments of a fictional scenario-which was the final task of the course-are analyzed within a twofold framework: First, the paper elaborates that there are both formal and non-formal agents playing roles in the production of urban space and knowledge of urban space. Not only a variety of formal institutions but also civil organizations and initiatives have emerged considerably since the 2010s in Turkey. Hence, the labor in the production of urban space is pluralized by diversified agents. Secondly, I point out that our generation has been witnessing an era of urban crisis with multiple dimensions such as urban resistance and repression, anti-participatory aggressive production processes of urban space, exploitation of young professionals' labor in parallel with unemployment, and the diminishing capacity of the profession. Through this twofold framework, I argue (and the fictional scenario accordingly ends in such a way) that young professionals could overcome the limits of the profession and generate new critical processes through prompting active citizenship and participation, including multiple actors of the production of urban space. This is the potential of the experiences of the last decade that we have just passed.
\end{abstract}

Keywords: Labor and work, production of urban space, civil organizations, active citizenship, Ilhan Tekeli 


\title{
Peki ya Genç Bir Meslek İnsanı Olsaydınız? İlhan Tekeli Dersinin Eleştirel Zemininde Bir Senaryo
}

$*$

\author{
Gülşah Aykaç² \\ ORCID: 0000-0002-6003-2704
}

Öz

Bu makale aktif yurttaşlık ve katılımı genç meslek insanlarının (mimar/plancı/kentsel tasarımcıların) kentsel krizin yaşandığı geçtiğimiz on yıldaki emek ve iş ilişkileri üzerinden sorgulayarak, İlhan Tekeli'nin lisansüstü dersinin eleştirel zeminini yeniden tartışmaya açmaktadır. Bu amaç doğrultusunda, dersin final ödevi olan kurgu bir kent senaryosu fragmanlara ayrilarak çift yönlü bir çerçeve ile irdelenmektedir. İlk olarak, kentsel mekân ve kentle ilgili bilginin hem formel hem de formel olmayan çoklu aktörler tarafindan üretildiğine dikkat çekiyorum. Bu bă̆lamda, kent üzerine çalışan sivil örgütlenmeler ve inisiyatiflerin bilhassa 2010'dan bu yana Türkiye'de önemli oranda arttı̆̆g gözlemine dayanarak; emeğin muhtelif aktörlerce çoğullaştığını söylemek mümkündür. İkincil olarak, genç meslek insanlarının bir kuşak olarak çok yönlü bir kentsel krizin içinden geçmekte olduğuna işaret ediyorum. Kentsel krizin kent mücadelesi ve baskısı, katılımo olmayan agresif çevre üretim süreçleri, genç meslek insanlarının emeğinin sömürülmesi; buna paralel olarak işsizlik ve meslek kapasitesinin düşmesi gibi farklı boyutları mevcuttur. Bu çift yönlü çerçeve ile temel olarak, genç meslek insanlarının son on yılın nevi şahsına münhasır deneyimi üzerinden yeni eleştirel süreçler oluşturma kapasitesi olduğunu; ve bu kapasitenin sivil örgütlenmelerin formel karar mekanizmalarna eklemlenmesi ve yurttaşların süreçlere aktif katılımı üzerinden üretilebileceğini iddia etmekteyim.

Anahtar Kelimeler: Emek ve iş, kentsel mekânın üretimi, sivil örgütlenmeler, aktif yurttaşlık, Illhan Tekeli

2 PhD student, METU, E-mail: gulsahaykac@gmail.com

idealkent @ Kent Araştırmaları Dergisi (Journal of Urban Studies)

http://idealkentdergisi.com

Geliş Tarihi Received Date: 04.11.2019 Kabul Tarihi Accepted Date: 25.04.2020 


\section{Introduction: An Imaginary Scenario for An Inexistent City}

It was my second semester in the doctoral program when I decided to take courses from the urban planning department of the faculty of architecture. I was lucky to participate in the course entitled "New Tendencies in Planning Thought" conducted by Prof. Dr. İlhan Tekeli while he was still teaching at Middle East Technical University in fall 2015-2016. The main objective of the course was finding critical crossings of the city, active citizenship, and participation. The graduate course was held around a round table where we, as participants of the course, dealt with the evolution of models of urban planning together with the evolution of planning theory. In each round table gathering, we discussed current urban trajectories with the expansion of a rich literature.

The course involved clearly defined tasks such as weekly readings, discussions, and collective conceptual mappings. At the beginning of the course, we were told that we would also complete a final assignment individually. As my classmates informed me, İlhan Tekeli's final assignments were popular in being challenging, creative, and unusual. Therefore, we were awaiting the announcement of the final assignment with curiosity and excitement in the first weeks. A few weeks passed, and I noted Tekeli's description of this assignment as follows:

What if you were a young professional in an imaginary city; could you convince the Mayor for better local governance in the solution of an imaginary problem? Write a scenario. In the scenario, you are a young professional; you have recently started to work for the municipality of "a city." Define the city; it could be imaginary or real, or mixed. Define the problem you face. Try to convince the Mayor of "a new way of local governance" on a current urban planning problem.

After the announcement, we started to ask Prof. Tekeli questions to clarify basic things about the assignment, such as the deadline or the format. According to Tekeli, these were unimportant details; he replied to each question by giving us flexibility in the format and deadline. "Whatever format you'd like. Dialogue, plain text, or any creative form you would like. Through this situation, discuss the contextualizations we have already discussed in the course." Behind our simple questions, we were indeed turned upside down, being taken from the round table of the studio to an imaginary desk of a municipality. In this new critical ground, Tekeli was giving us a productive space of fiction in order to 
question and challenge planning thought, urban problems, and, most importantly, our labor and position as young professionals.

Since I took Tekeli's course, I've still been returning to those round table discussions and the scenario I wrote in Turkish titled "A possible scenario for an inexistent city." I continue to see the impacts of this challenging assignment in my personal history while practicing the production of knowledge as a researcher and the production of urban space as both a citizen and a practitioner since my graduation from the architecture faculty in 2009. In the last decade of urban crisis that we have just passed, we, as young professionals who graduated from faculties of architecture and the built environment, have been taking roles in both controversial urban transformation processes and the newly emerging non-profit civil organizations and initiatives in Turkey. Within this context, this paper re-discusses the possibility of participating in the decisionmaking processes of the city as an architect/urban planner/urban designer working in a formal and governmental position through fragments of this imaginary scenario.

The paper is structured as a collage text, framing the fragments from the imaginary scenario with the literature on labor, work, and active participation. We did not have a chance to discuss the final assignment at the end of the semester. Hence, this paper attempts to discuss it with a twofold framework by extending the major discussions of the course, active citizenship and participation, in the discussion of the labor of young professionals.

In the scenario, an urban planner named Sevgi is employed by the municipality of her hometown just five years after graduation. Antalas, the fictional name of the fictional city, is a low-density city in terms of population, and a controversial urban transformation project is being conducted by the municipality. The problem with the urban transformation project is the social resistance against the demolishment of a neighborhood named Vadi. Vadi is a popularly known neighborhood with a unique sociospatial and sociocultural identity. Sevgi persuades the Mayor, who is a dominating agent in the decision-making processes of the municipality, by interpreting the social resistance and critical commitment of the Vadi neighborhood as the local value of the place. She suggests including civil organizations and initiatives that are against the project, claiming that those could be key agents to open decisionmaking processes to the community actively.

Following fragments of the scenario, the main claim is that there could be a possibility to participate in the production of urban space and lead participatory processes through our critical experiences of the production of space 
and knowledge of the last decade in Turkey. In spite of the precariousness of young professionals raised critically in terms of labor relations, our era could be input for rethinking the production of urban space beyond the limits of the profession and considering civil organizations and initiatives that pluralize the labor of the production of urban space by multiple actors. The crossing of the urban crisis of the last decade and our profession highlights this potential of promoting active citizenship and participation.

\section{Fragment 1: Formal and non-formal agents of production of urban space and pluralizing the labor}

Urban space is becoming a more controversial and complicated matter, while the density of population living in cities is drastically increasing within shifting layers of economical-political and ecological-political trajectories (UN, 2018). Attempting to develop tools to approach urban complexity, the production of knowledge on urban space is conducted by a myriad of networks. On the one hand, disciplines are collaborating with each other, such as urban anthropology, history, sociology, planning, and architecture, in institutions such as universities, research institutes, professional chambers, and NGOs. On the other hand, there are non-institutional, non-formal networks such as non-profit civil society organizations and initiatives working at the local level and producing critical knowledge on urban trajectories. These multiple grounds are providing plurality in the production of urban space and knowledge on urban space, bringing multiple actors together.

Within the preceding and subsequent consequences of the occupy-style protests that emerged in 2013, we (as citizens) have witnessed a rise in the establishment and activities of non-profit civil organizations and social initiatives, such as neighborhood collectivities, groups documenting the history of particular urban spaces, and artist collectives working on urban space and public art in Turkey. Those civil society organizations might not necessarily center the production of knowledge; however, they have taken an active role in the production of urban space. Since they gather in public space, they share their work outside of the sophisticated spheres of art galleries or institutions, prompting the participation of previously silenced and excluded citizens. We could claim that civil society organizations and initiatives have been searching for alternative and communal ways of production of urban space, which has articulated to the production of knowledge in Turkey. Therefore, those 
communities are creating social and political value in the context of a better communalized urban life.

The occupy-style urban protests and increasing social participation in the production of urban space since the 2010s have raised a tendency of glorifying "informal" modes of production of urban space. However, the glorification of the informal might bring about the separation of government and civil society, putting them on opposite sides. The recent complexity of urban space and social trajectories reveals that there is not a solely binary relationship between government and society, where government is taken as a formal institution to order society and society is reproduced through the formations of government. Instead, there are emergent sociospatial relations between various agents; therefore, "informal" is not directly the opposite of "formal" referring to a totalized understanding of urban agents, society, or government. Indeed, putting informal and formal in counter-positions in Turkey might be binding particular urban histories that exemplify that informal and formal urbanization have been shifting within each other in many different complex ways (Işık \& Pınarcioğlu, 2018, p. 50). Herein, I prefer to use "non-formal" instead of informal against the counter-positioning of informal/formal. Furthermore, formal and non-formal agents of the production of urban space, too, might shift into each other and create capacity. In this context, to focus on the labor relations of young professionals who work on the built environment (the urban planner in the fictive scenario, architects/urban planners/urban designers under forty years old) in Turkey could open critical grounds for discussing the labor of young professionals as both a formal and non-formal agent in our era of urban crisis and unemployment.

We architects/urban planners/urban designers, as young professionals who have graduated from architecture and built-environment faculties, have been active participants in and witnesses of the activities of such civil organizations and initiatives in Turkey in the last ten years. Those civil organizations and initiatives are producing both the urban space and critical knowledge of urban space, opening an active ground for citizens. The emergence of these groups is pluralizing the labor of the production of urban space and knowledge of urban space. However, we also might have a contradictory position working for formal institutions such as municipalities, the public sector, or private firms conducting urban transformation projects without any social concerns and without considering the participation of multiple agents in decision-making processes. We might be laboring without autonomy or authority, losing power in our work to shape the processes and products in 
the production of urban space. The main character in our scenario, the urban planner Sevgi, attempts to challenge her in-between position to affect decision-making processes in the municipality for which she works, questioning "active participation" at the local scale in her city. The fictional story starts with a depiction of a meeting room and other agents working for the municipality:

The long silence in the room was cut by a knock on the door, and the tea server Mevlüt entered the room without waiting for our response. Mevlüt left three cups of tea on the meeting table, which is an over-scaled piece of furniture for the tiny room. The urban planning director, Aylin P., took the first tea on her side; Mayor Mehmet took the second, and the third one was for me as a young urban planner. I was respected for moving back to my hometown after graduation to supervise the New Antalas Urban Renewal Project of the municipality. We were waiting for the Mayor to go over the report we had submitted. Mayor Mehmet was a tough person, not open to critical dialogues or new ideas, and you could regularly encounter this strictly conservative personality in our city of 100,000 people. The urban planning director, Aylin P., on the other hand, was highly respected as being the wife of talented doctor Rufat $P$. It was rumored that Rufat $P$. was capable of diagnosing and treating many illnesses, that he had even performed brain surgery in an urgent situation al though he was just a primary care physician. Aylin $P$. had been trying to criticize the decision-making processes of the municipality. From time to time, she had been effective; however, my colleagues said: "She got tired, she has the aura of her upcoming retirement, and she gave up resisting against the Mayor's strict way of directing the municipality." However, there was increasing tension between the municipality and the residents since the New Antalas Project had reached a phase in which a particular neighborhood named Vadi was to be subjected to mass demolition, so finally the Mayor had assigned me as a supervisor for the project, to mediate between agents of the municipality and also between the municipality and the Vadi neighborhood community. Aylin says she believes that I could affect the decision-making process, and possibly more than me, she believes in my father's close friendship with the Mayor.

\section{Fragment 2: The labor of architects/planners/urban designers in the era of urban crisis}

Although we, as young professionals, have witnessed both urban struggle and anti-participatory processes of urban transformation in the last era that we have just passed in Turkey, we rarely discuss our labor relations or work 
under transformation and its interconnection with the transformation of urban space. We have passed through an era of construction and destruction processes of contested urban projects, radical interventions to the urban fabric at the macro level, and the possibility of disasters that are expected to cause significant damages. In addition, we have witnessed the emergence and repression of massive occupy-style protests claiming civil spatial rights, the boom and boost of the economy depending on the building sector, increasing numbers of workplace accidents resulting in the death of site-workers, and rising levels of unrecorded employment and unemployment-related crises in the building sector (Aykaç \& Sert, 2018). There is a gap in terms of a research field investigating contemporary labor relations and the reproduction of the institution of our work, which is to say the institution of architecture/planning/urban design practices in Turkey.

There is, indeed, rising academic interest in contemporary modes of labor relations and "immaterial labor" under the changing conditions of production in the world since the 1970s (Kumar, 1989, p. 2-17). In this line, I would like to make reference to the main conceptualizations of labor and work by analyzing the meta-theoretical approach that Hannah Arendt elaborates in The Human Condition (1998). Concentrating on the experiences and processes of work, Arendt interprets the Marxist conception of labor at the beginning of the 1960s, which was accepted as a turnout in terms of globalizing production relations. The Marxist conception of labor has been influential in spatial research since the rise of industrialization in the mid-18th century. However, in the 1960s, there was a rising need to go beyond the abstract grasp of labor and question the emerging types of work in a globalizing world where technology was leading to the automatization and mechanization of labor (Sennet, 2008, p. 1-15), on the threshold of the rise of the neoliberal economy (Harvey, 2005, p. 1-5).

Marx and Engels conceptualize labor basically as human effort shaping life, society, and nature, produced and reproduced through the processes of laboring. The main concern of Marxist philosophy is that the exploitation of labor depends on the reproduction of labor relations, through which all work is distributed. In this context, Marx rejects the divisions of labor, such as the divisions of immaterial/material or skilled/unskilled labor, in order to glorify all kinds of labor against exploitation. At this point, Marxist philosophy points out mainly exploitative work conditions among factory workers and manual workers, such as the lack of leisure, lack of autonomy, toil, and insecurity of workplaces. However, Arendt claims that this glorification of labor 
might also mystify the transformed modes of labor relations, emerging power relations at work, different types of work, and the conception of work as an institution of labor relations in a changing world. Arendt offers a new theoretical frame, briefly stating that "laboring with body" including "laboring with the head (thinking)" and "working with the hands" are broad definitions of processes of life. Thus, Arendt distinguishes between labor and work, claiming that labor and work are interconnected activities; "the human condition of labor is life, and the human condition of work is the world" (Arendt, 1998, p. 6-8).

Hannah Arendt deliberately scrutinizes these two concepts, labor and work, attempting to point out that the reproduction of labor relations and work has critical dimensions that we should focus on. The abstract grasp of labor is widely perceived as "working with the hands" or "manual labor," and work is counted as employment or a job in our era. Departing from the opening of Hannah Arendt's phenomenological standpoint, contemporary sociologist Krishan Kumar (1989) supports the claim that production processes are becoming more and more dependent on "immaterial labor," and therefore Arendt attempts to unfold the concept of work. Because there are new types of work and non-market types of work, the number of factory workers or manual laborers has decreased, and there is a rising unemployment crisis in the world. The phenomenon of "class" as both an economic and a social category has become a more complicated matter in our century within the complexity of urban modes of production (Kumar, 1989, p. 2-17).

It is evident that there is an increasing sociospatial precariousness being shared unevenly by variant agents of production relations; hence, "class" is still an inherent part of labor relations and our urban life. Not only at the level of the workplace but also at the level of society, we practice "class" in different forms of labor relations. Based on the production of urban space, we, like all urban agents of production relations, as site workers and architects/planners/designers-workers, have a common problematic: the interconnected $e x-$ ploitation of human labor and exploitation of the environment. In this context, the group defined as white-collar, or in other words, professionals who could obtain an education in order to gain an occupation, are subjected to this interconnected exploitation. Peggy Deamer (2015) scrutinizes immaterial labor in architecture by defining architecture as work and the architect as a worker. She emphasizes that we are a part of service work. While we "design," for instance, a building project, we suffer from toil, lack of leisure, mechanization of our labor, and the impossibility of autonomy and authority to shape the 
process and product (Deamer, 2015). These working conditions are captured as exploitative conditions of the "worker"; hence, we, the professionals constituting the middle class, share the same ways of exploitation in architecture/urban planning/urban design practices in our century. Furthermore, our work is divided into newly emerging areas associated with technological development. There are new specialists and sub-fields in the built-environment disciplines, mostly concentrating on using technology as a tool in the production process. The technology allows the labor to gain speed and yet be fragmented. Deamer (2015) pictures the parallel relations and the interconnection of the exploitation of multiple laborers in the production processes of the environment, white-collar or blue-collar, professionals or manual workers. The definition of "architect as worker" attempts not to bind the commonality of these exploitative processes among different agents (Deamer, 2015; Sargin, 2017).

From a broader perspective, Guy Standing ([2011] 2014) defines professionals not as middle class or white-collar but as a new mass class, the precariat. Standing departs from the claim that the occupy movements were conducted mainly by this mass group "who has a common predicament" and who "is expected to endure labor and work at a lower level than the schooling it typically acquires" (p. vi-vii). There is a need to reframe our "work" beyond profession and occupation, but as a "historically and socially constructed institution of labor relations" (quoted from Kumar's definition of work, 1989, p. 4-5). Our work, then, is an institution reproduced by a "common predicament," increasing numbers of unemployed young people in the world since the 2008 economic crisis and the sudden rise and sharp fall of work capacity in Turkey in the last ten years. It is also an institution reproduced by municipal regulations, urban political trajectories, interrelated exploitation of labor, and the environment. The parallel rise of the exploitation of labor/environment and urban activism shows that our work has gained more internal contradictions. It is more visible than ever that our work has been exploited under the forces of changing production relations at the global level, which also causes serious environmental issues.

\section{Fragment 3: Crossings of active citizenship and participation}

Despite the limits and contradictions of our work as formal work, the research agenda widely captured the rise of the urban activism of the 2010s through the lens of active citizenship, which is conducted by volunteer, non-formal 
agents. Ayhan Kaya (2017) refers to the various conceptualizations of active citizenship in order to point out that these conceptualizations fit with what the multiple actors of occupy-style movements in Turkey experienced. Kaya underlines that active citizenship deepens an individual's grasp of others' lives and of living together. Hence, active citizenship produces a common sense of the production of space (Kaya, 2017, p. 4).

In her seminal article, Camilla Stivers (1990) elaborates that from its ancient theorization by Aristotle to Hannah Arendt's (1958) modern theorizations, active citizenship "draws on and develops the highest human capacities" and it "constitutes the good or virtuous of life" (p. 87). There could be different ways of manifesting active citizenship, such as the actions of civil organizations, initiatives, and grassroots movements, all of which implicitly become a core matter of the participation of multiple actors in the decisionmaking processes of urban planning. Participation could be problematized as the search for the use of the knowledge and urban experiences of individuals to reach the insights of larger groups (Fitzgerald et al., 2016). At this point, Stivers (1990) argues that active citizenship "can be enacted in an agency setting" through the inclusion of active citizens in administrative processes and by establishing interaction between citizens and administrators, or, in other words, between non-formal and formal agents (p. 86-105).

What should be the agenda of our built-environment and urban-related work under these consequences after the 2010s? Active citizenship and participation at this point bring two fragments of the scenario together: The first fragment unfolds the rising plurality of labor on the urban space that emerged within urban activism, and the following fragment unfolds the growing precariousness of the work of architects/urban planners/urban designers. New planning thought underlines that new strategies such as ensuring common sense, structuring horizontal relations, and mediating between formal and non-formal actors could be developed to prompt active citizenship and participation in the decision-making processes (Tekeli, notes from "New Tendencies in Planning Thought" course, 2016; Tekeli, 2012a, 2012b, $2018,2019 b)$. Our work has the capacity to search for these strategies for positioning as neither an authority nor a citizen, or neither a formal nor a nonformal agent, but both.

In the scenario, at this point, urban planner Sevgi attempts to persuade the Mayor to stop the New Antalas Project in its stage of demolishing the Vadi neighborhood and to redesign the renewal project processes together with 
questioning for better local governance. Better local governance should consider emerged active citizenship for the potential for active participation in the decision-making processes. According to the Mayor, it is not plausible to stop the process, because a shopping complex will be constructed in the Vadi neighborhood. The Mayor believes that this shopping complex project will turn the neighborhood into a new attraction center of the city with the help of economic investment from outsiders. However, Sevgi claims that better local governance is only possible when the residents and their non-governmental organizations participate in the decision-making processes of the district municipality, which is the leading authority and structures its authority without dialogue with the citizens.

There is social value that emerged in Vadi with the collective and communal activities of insiders and outsiders of the neighborhood, making the neighborhood a special place for Antalas. This social value lies in the nonprofit civil organizations and initiatives including a neighborhood collective, a local newspaper initiative providing news and critiques about the urban daily life of Antalas, a public art initiative, a neighborhood garden initiative, a communal laundry center for those who do not have washing machines at home, and a book-sharing collective. These groups have been producing active sociospatial dynamics since the 2010s. The participants are either residents living in the neighborhood or people living outside and gathering with Vadi residents in Vadi. Thus, the diverse community of these organizations is composed of not only a group of people living together in the neighborhood but also citizens from other districts. As İlhan Tekeli points out (2019a), "community" and communal production of space could be established through not necessarily a shared place but rather common grounds such as the consensus that emerged about the Vadi neighborhood (Tekeli, 2019a, p. 35). The common ground of the Vadi community resisting the urban transformation project is the communal experience of urban activism in the making of space.

- Mayor: "Miss Sevgi, I read your report. Very well written, well done. But what are the values of Antalas? Does Vadi have a local urban value? It is the oldest neighborhood in the city, and the buildings are wearing down! All the residents coming to us, making difficulties in doing our job here, are from the Vadi neighborhood! They have a newspaper, and they are writing against us.

- Aylin: "Dear Mayor, I agree with you, but I suggest we listen to Sevgi elaborate on her report." 
- There was rising tension in the room. The Mayor was not opening grounds for dialogue. Aylin suddenly seemed less hopeful to me. The level of my discomfort was rising in the conversation; I was questioning why I was there, maybe I should not have come back to work for the municipality in Antalas! There was no communication between the municipality and the Vadi community; the city council was selected by a group of people who would agree with the Mayor under any conditions. I felt like I could better fit a volunteer job at the Vadi newspaper. I forced myself to believe in my report, elaborating on the potential of Vadi against the proposal of the New Antalas Project that would lead to fragile conditions in Vadi, diminishing the emerged social urban activism. I thought that I should not give up and I needed to convince the Mayor. I took a sip from my second cup of tea.

- "Dear Mayor," I said, "better local governance could be designed through how we look at the 'local' urban values. The locality is a plurality of various agents under ongoing sociospatial change. We have social value, which is the emerged urban activism and emerged agents as participants of civil organizations and initiatives in Vadi. This value belongs to all of the city, to Antalas. If we could take these civil organizations at the center of active citizenship at the local level and if we could prompt active participation by including these organizations as key stakeholders, we would take less risk. We could share the labor in the decisionmaking processes, since we could establish a team. You would take less risk being the Mayor; you don't need to decide for yourself. We should organize a new election for the city council, invite those groups to participate in the election, and then move the city council forward, searching for an inclusive, open, participatory process. Dear Mayor, we will design active participation in the decisionmaking processes for Antalas and we can start with rethinking the Vadi neighborhood stage. You will be a trendy figure in the Vadi newspaper with a bold title: 'The Mayor invited Vadi to completely remake the New Antalas Urban Renewal Project'."

\section{Conclusion: The possibility of working together}

- After hearing about that title in the Vadi newspaper, the Mayor suddenly changed his tone and attitude. Aylin smiled and added some more good things about how a mayor could become a significant figure by listening to the community and stopping a project for economic development in Turkey. Hence, I understood that I was moving in the right direction. 
- "Dear Mayor," I said, "we will first invite a committee of specialists to develop participatory processes in local governance; that is the conclusion part of my report. We will immediately declare that the project is stopped, we are working for better local governance, and the Vadi neighborhood will be part and parcel of the decision-making processes actively. Moreover, while we are thinking about the participation issue, I propose that we address some immediate problems of the neighborhood, such as the establishment of laundry centers, and besides, we can add a room to such centers, a room for making and drinking coffee and tea. These small steps supporting civil organizations might also help to change the negative bias of the community and all citizens about our municipality."

- We ended the meeting and I left the Mayor's room with Aylin with hope and excitement for a better future. The only thing I was concentrating on was working more on the report. I was thinking of names from civil organizations of Antalas and my teachers at the university to schedule initial meetings. I opened the door of my room without a feeling of estrangement from my work for the first time. I was about to close the door, but Mevlüt entered the room with me and gave me one more cup of Turkish tea with one sugar - that was how I used to drink tea:

- Mevliut: "Miss Sevgi, I've heard that you saved our houses in Vadi. Of course, I was already sure that our dear Mayor wouldn't demolish our houses, but... Don't hesitate if you want to eat something with tea; I can immediately make you a sandwich."

- Mevlüt's thankful tea on my desk and the work I would do made me feel satisfied for the first time in a long time at the municipality, and I felt like we were working for the same thing, for a good life in our city, Antalas.

Although Illhan Tekeli's course enhanced our perspectives on active citizenship and participation around the theory and history of planning, Tekeli directed the main problematics of the course to us, being young professionals, architects/urban planners/urban designers, by giving us a final challenging assignment that forced us to put ourselves in a fictional desk with a fictional municipality of a fictional city. Through this lens, we looked at our work and the labor processes of our generation, which is a generation of the era of urban crisis and resistance, processes of anti-participatory transformation projects, deep legal changes in planning specifically after the 2010s, rising unemployment for young workers and professionals, and the rising exploitation of our labor. Furthermore, we are a generation that has been actively participating in or witnessing the pluralization of labor in the production of urban space. 
This paper has attempted to re-open the critical grounds of Tekeli's graduate course with a twofold framework. First, I pointed out that there is not a counter-position between non-formal and formal agents in the production of urban space. Rather, there are more intricate processes of the production of urban space and knowledge of urban space by a multitude of actors. In particular, non-profit civil organizations and initiatives that emerged after the 2010 s in Turkey have played a significant role in practicing active citizenship. The labor of architects/planners/urban designers is pluralized by these multiple actors and the platforms they established. Second, I claimed that there has been an ongoing debate around the labor of professionals because of the growing crisis of exploitation of the labor of young architects/urban planners/urban designers, paralleling the deaths of construction-related workers, unemployment, and the diminishing capacity of our work in the world since 2008. Through this twofold framework, I finally suggested that political and economic trajectories have led to negative effects among young professionals. However, at the same time, this might open ground for our generation to question the current conditions communally and critically in order to mediate between multiple actors such as active citizens and formal agents in order to lead participatory decision-making processes in urban planning.

The challenging final assignment and İlhan Tekeli's course as an entire process were strongly influential in this line of not alienating my labor and work. Tekeli's course invited us, as active urban agents in the production of space and knowledge, to seek leading alternative processes. It opened crucial space with the implication that it is worthwhile to discuss young professionals'-our generation's-labor and work. We are both formal and non-formal agents of production of urban space, witnessing urban resistance and repression in the last decade of urban crisis, while growing more and more precarious under the political, economic, and ecological consequences at national and transnational scales. This situation has enabled us to reassess our citizenship and the role of being architects/urban planners/urban designers strategically.

\section{Kaynakça/References}

Arendt, H. (1958/1998). The human condition (2nd ed.). Chicago: University of Chicago Press. 
Aykaç, G., and Sert, E. (2018). Türkiye'de mimarlığın emek süreçlerini yeniden tartışmak (Rethinking the Processes of Architecture in Turkey). Moment Dergi, 5(2), 219-237. doi: 10.17572/mj2018.2.219237

Deamer, P. (Der.), (2015). The architect as worker - immaterial labor, the creative class, and the politics of design. New York \& London: Bloomsbury Academic.

Fitzgerald, C., McCarthy, S., Carton, F., Connor, Y., Lynch, L. and Adam, F. (2016). Citizen participation in decision-making: can one make a difference? Journal of Decision Systems, 25(1), p. 248 260. doi: 10.1080/12460125.2016.1187395

Harvey, D. (2005). A brief history of neoliberalism. Oxford \& New York: Oxford University Press.

Kaya, A. (2017). Right to public space: social movements and active citizenship in Turkey. Research and Policy on Turkey, 2(1), 1-9. doi:10.1080/23760818.2016.1272273

Kumar, K. (1989). The social culture of work: work, employment and unemployment as ways of life. Kenneth Thompson (Ed.), in Work, employment and unemployment: perspectives on work and society (p.2-17). Philadelphia: Open University Press.

Işık, O., and Pınarcıoğlu, M. M. (2001/2018). Nöbetleşe yoksulluk Sultanbeyli örneği (2.baskı). Istanbul: İletişim Yayınları.

Sargın, G. A. (2017). İktidarın mimar-öznesinden devrimci siyasi-özneye:Yaratıcılık miti, burjuva ideolojisi ve devlet aygıtları: Kısa değinmeler. Arredamento Mimarlık, $13,78-80$.

Sennett, R. (2008). The Craftsman. New Haven: Yale University Press.

Standing, G. ([2011] 2014). The precariat: the new dangerous class. New York, NY: Bloomsbury.

Stivers, C. (1990). The public agency as polis: active citizenship in the administrative state. Administration $\mathcal{E}$ Society, 22(1), 86-105. doi:10.1177/009539979002200105

Tekeli, İ. (2012a). Katılımcı demokrasi, sivil ağlar ve sivil toplum kuruluşları. In Türkiye için STK'lar ve katılımo demokrasi yazıları, İlhan Tekeli Toplu Eserler. 22, (p. 4055). Istanbul: Tarih Vakfi Yurt Yayınları.

Tekeli, İ. (2012b). Bir demokrasi projesi olarak yerel habitatlar. In Türkiye için STK'lar ve katılımcı demokrasi yazıları, İlhan Tekeli Toplu Eserler. 22, (p. 235-246). Istanbul: Tarih Vakfi Yurt Yayınları.

Tekeli, İ. (2018).Ortak olanın keşfi geliştikçe demokrasi taleplerimizin dayanağı da genişliyor. İktisat ve Toplum, 97, 27-31.

Tekeli, İ. (2019a). Bilgi toplumuna doğru yol alırken, kent yöneticileri ve kent plancıları olarak komünite kavramını düşünmemiz ve ona yeni işlevler yüklememiz gerekiyor. Iktisat ve Toplum, 100, 27-35.

Tekeli, İ. (2019b). Scientific knowledge and decision-making in planning, understanding emotional aspects. Ayda Eraydin and Klaus Frey (Ed.), in politics and conflict in governance and planning (p. 227-242). New York \& London: Routledge.

UN (2018). The World's Cities in 2018. Accessed on 30 March 2019 https://www.un.org/en/events/citiesday/assets/pdf/the_worlds_cities_in_2018_data_booklet.pdf. 